\title{
Corn silage versus corn silage:alfalfa hay mixtures for dairy cows: Effects of dietary potassium, calcium, and cation-anion difference
}

\author{
R. A. Erdman, ${ }^{1}$ L. S. Piperova, and R. A. Kohn \\ Animal and Avian Sciences Department, University of Maryland, College Park 20742
}

\section{ABSTRACT}

Corn silage (CS) has replaced alfalfa hay $(\mathrm{AH})$ and haylage as the major forage fed to lactating dairy cows, yet many dairy producers believe that inclusion of small amounts of alfalfa hay or haylage improves feed intake and milk production. Alfalfa contains greater concentrations of $\mathrm{K}$ and $\mathrm{Ca}$ than corn silage and has an inherently higher dietary cation-anion difference (DCAD). Supplemental dietary buffers such as $\mathrm{NaHCO}_{3}$ and $\mathrm{K}_{2} \mathrm{CO}_{3}$ increase DCAD and summaries of studies with these buffers showed improved performance in CSbased diets but not in AH-based diets. We speculated that improvements in performance with $\mathrm{AH}$ addition to CS-based diets could be due to differences in mineral and DCAD concentrations between the 2 forages. The objective of this experiment was to test the effects of forage (CS vs. $\mathrm{AH}$ ) and mineral supplementation on production responses using 45 lactating Holstein cows during the first $20 \mathrm{wk}$ postpartum. Dietary treatments included (1) 50:50 mixture of AH and CS as the forage (AHCS); (2) CS as the sole forage; and (3) CS fortified with mineral supplements $\left(\mathrm{CaCO}_{3}\right.$ and $\left.\mathrm{K}_{2} \mathrm{CO}_{3}\right)$ to match the $\mathrm{Ca}$ and $\mathrm{K}$ content of the AHCS diet (CSDCAD). Feed intake and milk production were equivalent or greater for cows fed the CS and CS-DCAD diets compared with those fed the AHCS diet. Fat percentage was greater in cows fed the CS compared with the AHCS diet. Fat-corrected milk (FCM; 3.5\%) tended to be greater in cows fed the CS and CS-DCAD diets compared with the AHCS diet. Feed efficiencies measured as FCM/dry matter intake were 1.76, 1.80, and 1.94 for the AHCS, CS, and CS-DCAD diets, respectively. The combined effects of reduced feed intake and increased FCM contributed to increased feed efficiency with the CS-DCAD diet, which contained $1.41 \% \mathrm{~K}$ compared with $1.18 \% \mathrm{~K}$ in the $\mathrm{CS}$ diet, and we speculate that this might be the result of added dietary $\mathrm{K}$ and DCAD effects on digestive efficiency. These results indicate no advantage to including $\mathrm{AH}$ in CS-based diets, but

Received March 5, 2011

Accepted June 1, 2011.

${ }^{1}$ Corresponding author: erdman@umd.edu suggest that improving mineral supplementation in CSbased diets may increase feed efficiency.

Key words: corn silage, alfalfa, dietary cation-anion difference (DCAD), dairy cow

\section{INTRODUCTION}

Corn silage has become the predominant forage source for dairy cows in the United States because of its high yield per unit of land area relative to alternative forages, ease of harvest, and preservation characteristics. Over the past $20 \mathrm{yr}$, corn silage production in the top 5 dairy states (California, Wisconsin, Idaho, New York, and Pennsylvania) has increased by $27 \%$, whereas alfalfa acreage and hay production has declined (USDA-NASS, 2010). Surprisingly, a major question $40 \mathrm{yr}$ ago dealt with the feasibility of all-silage diets and in particular, the use of corn silage as the sole forage (Hemken and Vandersall, 1967). Several studies (Thomas et al., 1970; Trimberger et al., 1972; Grieve et al., 1980) demonstrated production equivalency with the use of corn silage as the sole forage compared with diets containing mixtures of corn silage and alfalfa or grass hay. Dhiman and Satter (1997), in a study comparing all alfalfa haylage compared with mixtures of alfalfa haylage and corn silage, concluded that diets with one- to two-thirds corn silage should be fed, based on economic responses and potential reductions in $\mathrm{N}$ losses to the environment.

Surveys of high-producing herds in the United States showed that corn silage was being used in $91 \%$ of survey herds in 2001 (Kellogg et al., 2001) compared with just $67 \%$ of the herds surveyed in 1993 (Jordan and Fourdraine, 1993), confirming the trend of increased use of corn silage. However, these same surveys also showed that use of alfalfa hay and haylage, respectively, increased from 49 to $58 \%$ and 56 to $81 \%$ of the herds surveyed in 1993 and 2001, suggesting that dairy producers preferred feeding diets using mixtures of forages rather than a single forage.

Jasaitis et al. (1987) showed that in vitro buffering capacities of feeds were strongly related to their ash or mineral content. Alfalfa has almost twice the ash content of corn silage (NRC, 2001), with most of the 
difference due to $\mathrm{K}$ and $\mathrm{Ca}$ content. Because of the increased $\mathrm{K}$ content, alfalfa also has an inherently greater DCAD than corn silage (467 vs. $229 \mathrm{mEq} / \mathrm{kg}$ of diet DM; NRC, 2001). Hu and Murphy (2004), in a metaanalysis of previously published experiments, reported that maximal milk yield and DMI occurred at DCAD of 340 and $400 \mathrm{mEq} / \mathrm{kg}$ of DM, respectively. This implied that differences in forage DCAD might also play a role in perceived or real production responses to inclusion of alfalfa hay in corn silage based diets.

In a review of studies evaluating the effect of dietary buffers in lactating dairy cow experiments, Erdman (1988) found that dietary buffers increased feed intake, milk fat concentration, FCM production, and rumen $\mathrm{pH}$ in corn silage-based diets but not in alfalfa haybased diets. The author concluded that the differences in responses due to forage were from differences in inherent feed buffering capacity and increased chewing activity due to the feed particle size of alfalfa hay as compared with corn silage. However, dietary buffers such as $\mathrm{NaHCO}_{3}$ and $\mathrm{K}_{2} \mathrm{CO}_{3}$ also increase DCAD. Kohn (2000), based on the strong ion theory of acid-base regulation of Stewart (1983), suggested that dietary strong ion balance $(\mathrm{K}, \mathrm{Na}$, and $\mathrm{Cl})$ or DCAD exerted a major influence on rumen $\mathrm{pH}$ and that responses to dietary buffers were due to changes in strong ion balance in the diet.

To our knowledge, comparisons of the equivalency of alfalfa hay or haylage compared with corn silage have never considered differences in dietary mineral concentrations or DCAD. Our hypothesis was that the real or perceived need by dairy producers to include at least some alfalfa hay or haylage in corn silage-based diets is actually due to changes in dietary mineral and DCAD concentrations. The objective of this experiment was to determine if mineral concentrations affected DMI and milk production responses in diets where corn silage was the sole forage as compared with diets containing a mixture of alfalfa hay and corn silage.

\section{MATERIALS AND METHODS}

\section{Experimental Design}

This experiment was conducted under a protocol approved by the University of Maryland Institutional Animal Care and Use Committee. Forty-five Holstein dairy cows were used in the experiment. At parturition, cows were blocked by age (21 primiparous vs. 24 multiparous) and calving date and randomly assigned within block to 1 of 3 dietary treatments fed from parturition through wk 20 postpartum. Treatment diets consisted of (1) a control diet containing $55 \%$ forage using equal portions of chopped alfalfa hay and corn silage (AHCS) on a DM basis; (2) $55.8 \%$ corn silage (CS); or (3) $55.8 \%$ corn silage plus mineral supplements $\left(0.97 \% \mathrm{CaCO}_{3}\right.$ and $\left.0.42 \% \mathrm{~K}_{2} \mathrm{CO}_{3}\right)$ to mimic the increased $\mathrm{Ca}, \mathrm{K}$, and DCAD content in the AHCS diet (CS-DCAD; Table 1). Alfalfa hay was purchased in 2 lots from a common supplier based on similar protein and NDF analysis provided by the supplier. Corn silage came from 2 lots: a 2004 harvest stored in an upright silo and a 2005 harvest stored in a bunker silo. The first and second lots of alfalfa hay and corn silage were fed consecutively as the first lot of each ran out approximately midway through the experiment. Diets were formulated to meet NRC (2001) standards for a $650-\mathrm{kg}$ mature-weight cow producing $45 \mathrm{~kg}$ of $3.8 \%$ fat, $3.1 \%$ protein milk at peak lactation (60 d postpartum).

Cows were housed in sawdust-bedded tie stalls and individually fed treatment diets once daily as a TMR. Cows were milked twice daily in a milking parlor at 0600 and $1700 \mathrm{~h}$, and milk production was recorded electronically at each milking. Milk samples from consecutive milkings were collected weekly and analyzed separately for fat, protein, lactose, SCC, and MUN by infrared analysis (Foss MilkoScan, Foss Food Technology Corp., Eden Prairie, MN). Cow BW was recorded weekly throughout the study. Forage and ingredient DM were measured weekly, and the TMR was adjusted accordingly to maintain a constant forage-to-concentrate ratio on a DM basis. Weekly samples of forages and individual ingredients were frozen at $-20^{\circ} \mathrm{C}$ and then composited by treatment for chemical analysis at a commercial laboratory (Cumberland Valley Analytical Services Inc., Hagerstown, MD). Chemical composition of the individual diets was based on the amounts of the individual ingredients offered within each diet (DM basis; Table 1).

\section{Statistical Analysis}

Feed intake, BW, milk yield, milk composition, and milk component yields were averaged by cow and week postpartum. Net energy intake was calculated as the product of feed $\mathrm{NE}_{\mathrm{L}}$ concentration (Table 1) and DMI. Milk energy (E) was calculated using formula in NRC (2001). Dry matter intake for feed efficiency (FE) was calculated using weekly averages of $3.5 \%$ FCM and DMI as FCM/DMI. Net energy efficiency $\left(\mathbf{N E}_{\text {eff }}\right)$ was calculated as milk E divided by $\mathrm{NE}_{1}$ intake. Data were analyzed as a randomized complete block design using the Mixed procedure in SAS software (version 8.2, 2004; SAS Institute, Cary, NC). The statistical model included the effects of treatment, block, cow with block, week postpartum, and week postpartum by treatment interaction. Cow within block was delineated as the random effect in the model and was used to test treatment 
Table 1. Ingredient and chemical composition of experimental diets

\begin{tabular}{|c|c|c|c|}
\hline \multirow[b]{2}{*}{ Item } & \multicolumn{3}{|c|}{$\operatorname{Diet}^{1}$} \\
\hline & AHCS & CS & CS-DCAD \\
\hline \multicolumn{4}{|l|}{ Ingredient, $\%$ of diet DM } \\
\hline Corn silage & 27.60 & 55.82 & 55.78 \\
\hline Alfalfa hay & 27.39 & - & - \\
\hline Ground high-moisture shelled corn & 22.78 & 9.02 & 9.01 \\
\hline Dried citrus pulp & 2.05 & 10.69 & 8.79 \\
\hline Soybean hulls & 6.28 & 3.22 & 3.86 \\
\hline Soybean meal (minimum 48\% CP) & 5.26 & 10.47 & 10.74 \\
\hline Expeller soybean meal ${ }^{2}$ & 6.28 & 7.47 & 7.73 \\
\hline Corn gluten meal & 1.65 & 1.88 & 1.90 \\
\hline Potassium carbonate & - & - & 0.42 \\
\hline Calcium carbonate & 0.01 & 0.77 & 0.97 \\
\hline Salt & 0.48 & 0.46 & 0.42 \\
\hline Magnesium oxide & 0.01 & 0.01 & 0.04 \\
\hline Dicalcium phosphate & 0.13 & 0.04 & 0.05 \\
\hline Elemental sulfur & - & 0.06 & 0.20 \\
\hline Vitamins and trace minerals ${ }^{3}$ & 0.08 & 0.09 & 0.10 \\
\hline Feed cost,${ }^{4} \$ / \mathrm{Mt}$ of DM & 275.64 & 265.60 & 272.69 \\
\hline \multicolumn{4}{|l|}{ Chemical composition, DM basis } \\
\hline DM, \% & 61.10 & 48.32 & 48.23 \\
\hline $\mathrm{NE}_{\mathrm{L}},{ }^{5} \mathrm{Mcal} / \mathrm{kg}$ & 1.66 & 1.72 & 1.70 \\
\hline $\mathrm{CP}, \%$ & 17.43 & 17.21 & 17.23 \\
\hline $\mathrm{RUP}^{6} \%$ & 6.36 & 7.52 & 7.24 \\
\hline $\mathrm{RDP}^{6} \%$ & 11.07 & 9.69 & 10.00 \\
\hline NDF, $\%$ & 33.30 & 31.23 & 31.27 \\
\hline $\mathrm{ADF}, \%$ & 22.19 & 17.82 & 18.02 \\
\hline Ash, $\%$ & 7.31 & 5.91 & 6.76 \\
\hline $\mathrm{NFC}^{7} \%$ & 38.9 & 42.6 & 41.6 \\
\hline $\mathrm{K}, \%$ & 1.36 & 1.18 & 1.41 \\
\hline $\mathrm{Ca}, \%$ & 0.77 & 0.75 & 0.83 \\
\hline $\mathrm{P}, \%$ & 0.41 & 0.35 & 0.42 \\
\hline $\mathrm{Na}, \%$ & 0.26 & 0.20 & 0.24 \\
\hline $\mathrm{Cl}, \%$ & 0.65 & 0.44 & 0.46 \\
\hline $\mathrm{Mg}, \%$ & 0.23 & 0.20 & 0.22 \\
\hline $\mathrm{S}, \%$ & 0.29 & 0.29 & 0.31 \\
\hline $\mathrm{DCAD},{ }^{8} \mathrm{mEq} / \mathrm{kg}$ of $\mathrm{DM}$ & 281 & 251 & 336 \\
\hline
\end{tabular}

${ }^{1}$ Cows were fed diets containing a 55\% forage including a 50:50 mixture of alfalfa hay and corn silage (AHCS), corn silage alone (CS), or corn silage plus minerals (CS-DCAD) to mimic those in the AHCS diet.

${ }^{2}$ Soyplus (West Central Cooperative, Ralston, IA).

${ }^{3}$ Formulated to provide $0.3,0.2,0.6,15,10,15$, and $50 \mathrm{mg} / \mathrm{kg}$ of added $\mathrm{Se}, \mathrm{Co}, \mathrm{I}, \mathrm{Fe}, \mathrm{Cu}, \mathrm{Mn}$, and $\mathrm{Zn}$, respectively, and $3,500,1,000$, and $25 \mathrm{IU} / \mathrm{kg}$ of added vitamins $\mathrm{A}, \mathrm{D}$, and $\mathrm{E}$, respectively, to the diet DM.

${ }^{4}$ Estimated using May 2011 Northeast prices for diet components.

${ }^{5}$ Estimated based on $3 \times$ maintenance $\mathrm{NE}_{\mathrm{L}}$ value of the diet.

${ }^{6}$ Estimated using ingredient values from NRC (2001) assuming a diet containing 50\% forage consumed at $4 \%$ of BW.

${ }^{7} \mathrm{NFC} \%=100-(\mathrm{CP} \%+\mathrm{NDF} \%+\operatorname{ash} \%+$ fat $\%)$, where measured ingredient values of dietary $\mathrm{CP}, \mathrm{NDF}$, and ash were used and estimated values for fat taken from NRC (2001).

${ }^{8}$ Dietary $\mathrm{K}+\mathrm{Na}-\mathrm{Cl}, \mathrm{mEq} / \mathrm{kg}$ of $\mathrm{DM}$.

and block effects, whereas week postpartum and week by treatment interaction were tested using the residual error. Two preplanned contrasts were used to examine forage (AHCS vs. CS) and forage plus minerals (AHCS vs. CS-DCAD) effects using cow within block as the error term. A probability of $P \leq 0.05$ was considered statistically significant and $P \leq 0.10$ was considered a trend in the statistical analysis. Because of severe clinical mastitis that caused a permanent $40 \%$ loss in milk production, data were omitted from 2 cows after wk 16 ( 1 cow on the AHCS and 1 on the CS-DCAD treatment) and 1 cow after wk 18 (CS-DCAD treatment). Because of missing data, treatment responses are reported as least squares means in Table 2, where the largest SEM for an individual treatment mean was reported as the pooled SEM.

\section{RESULTS}

Ingredient and chemical composition of the experimental diets are in Table 1. Because of the large differences in energy, protein, and fiber concentrations 
Table 2. Effect of a 50:50 alfalfa hay-corn silage (AHCS) mixture, corn silage alone (CS) or corn silage plus dietary cations and anions (CSDCAD) comparable to those in AHCS on feed intake, milk production and composition, and feed efficiency in early-lactation dairy cows

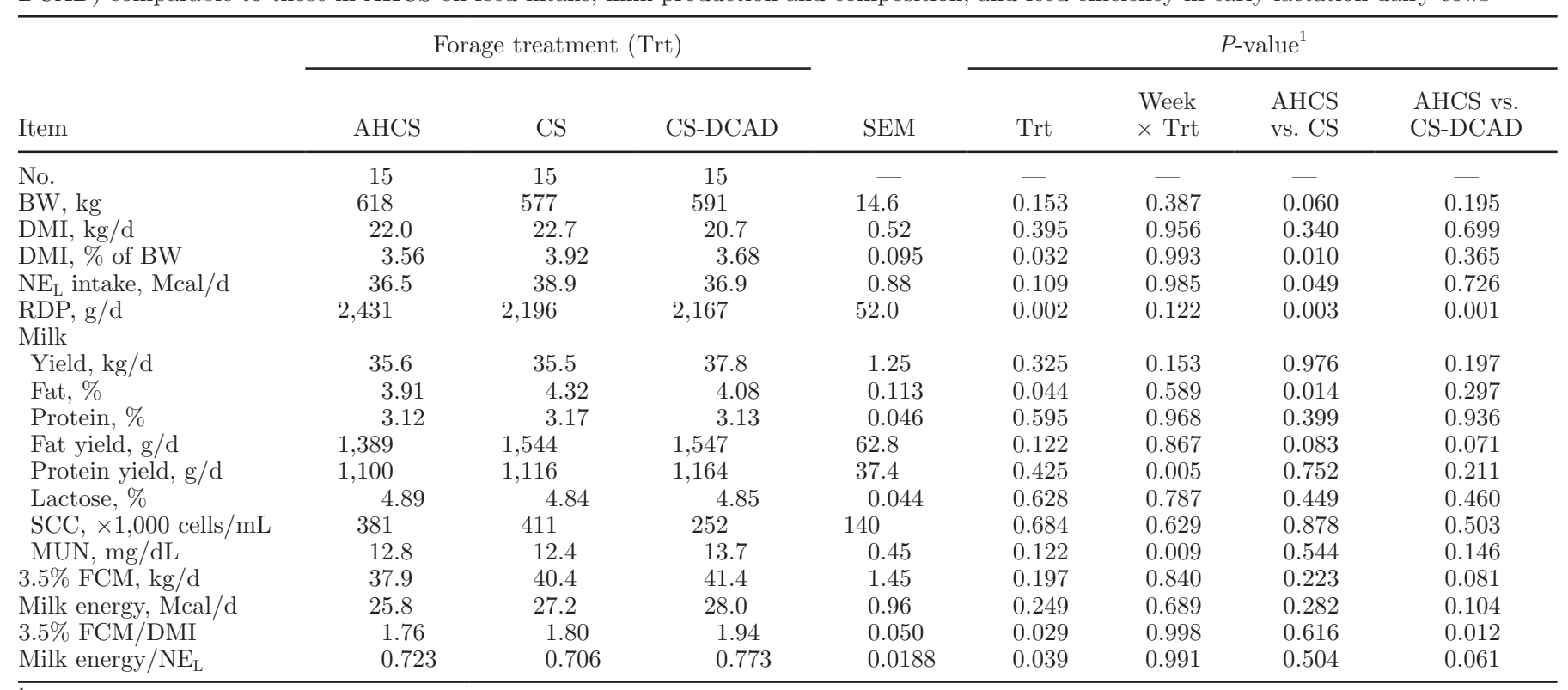

${ }^{1}$ Probability that the treatment, comparison, or interaction effects were not different from zero.

between alfalfa hay and corn silage, cows fed the CS and CS-DCAD treatments were fed 14 percentage units less high-moisture corn, which was balanced with 8 percentage units more citrus pulp and 6.5 percentage units more soybean meal and expeller soybean meal to balance the energy, protein, and fiber concentrations between the experimental diets. Because of the DM differences between alfalfa hay and corn silage, diet DM percentage was 13 percentage units greater in the AHCS than in the CS and CS-DCAD diets. Because of the DM content, TMR ingredient sorting might be a concern in the AHCS diet, but unfortunately we did not have TMR sieve data from the mixed diets and refusals. Sorting effects would likely be greatest where feed refusals are minimal $(<5 \%)$, whereas the actual refusals averaged by study week across treatment were $21 \%$, which should have minimized sorting. Estimated dietary $\mathrm{NE}_{\mathrm{L}}$ was lower in the AHCS compared with the CS and CS-DCAD treatments due to higher than expected ADF and NDF contents in the second lot of alfalfa hay used in the study. By design, dietary Ca and $\mathrm{K}$ were similar between the AHCS and CS-DCAD diets but higher in those diets compared with the CS treatment.

Feed intake and BW were not affected by treatment although a trend $(P=0.06)$ was observed for decreased BW in the CS cows (Table 2). Because of smaller BW for cows fed the CS diet, intake as a percentage of BW was 0.36 percentage units greater $(P=0.01)$ in the CS treatment compared with AHCS. Milk production
(Table 2) was not affected by treatment and averaged $36.3 \mathrm{~kg} / \mathrm{d}$ over the $20 \mathrm{wk}$ experiment reflecting the use of both primiparous and multiparous cows in the study. Milk fat percentage was reduced $(P=0.014)$ in the AHCS compared with the CS-fed cows. A trend was noted for an approximately $150 \mathrm{~g} / \mathrm{d}$ increase in fat yield between the AHCS and CS $(P=0.08)$ and the AHCS and CS-DCAD $(P=0.07)$ treatments. Although overall protein yield was not affected by treatment, a week by treatment interaction $(P=0.005$; data not shown $)$ occurred, whereby protein yields were greater during the first 4 wk postpartum in the CS and CS-DCAD treatments than in the AHCS treatment. Milk lactose, SCC, and MUN were not different among treatments. For MUN, a week by treatment interaction $(P=0.009$, data not shown) occurred, where MUN in the CS group was lower during the last $10 \mathrm{wk}$ of the study compared with the other treatments.

Because of differences in milk yield and milk fat content, 3.5\% FCM and milk energy yields were numerically greater in cows fed the CS diet compared with the AHCS diets and a trend $(P=0.08)$ was observed for increased FCM in the CS-DCAD compared with the AHCS cows. Reflecting differences in FCM production and the reduced DMI in the CS-DCAD treatment, a significant treatment effect $(P=0.029)$ occurred on FE, which was 0.18 units $(P=0.012)$ and 0.14 units greater in the CS-DCAD than the AHCS and CS treatments, respectively. However, FE did not differ between the AHCS and CS treatments. A treatment effect $(P=$ 
$0.039)$ for $\mathrm{NE}_{\text {eff }}$ and a trend $(P=0.061)$ for increased $\mathrm{NE}_{\text {eff }}$ were observed with CS-DCAD compared with AHCS similar to that shown between these treatments for FE.

\section{DISCUSSION}

This study found no advantage to inclusion of alfalfa at a rate equal to corn silage based on milk production and feed intake data. This is consistent with the results of previous studies that showed inclusion of either grass or legume hay in silage-based diets was not needed (Hemken and Vandersall, 1967; Thomas et al., 1970; Trimberger et al., 1972; Grieve et al., 1980). Still, dairy producers that use corn silage as the principal forage also frequently include alfalfa hay as a small proportion (10-15\%) of the diet DM.

Efforts were made during diet formulation to mimic the mineral concentrations of the CS-DCAD diet to be equal those in the AHCS diet, including the $\mathrm{K}$, Ca, ash, and DCAD concentrations. By design, dietary K was 0.18 and 0.23 percentage units higher (Table 1 ) in the AHCS and CS-DCAD treatments compared with CS, but similar between the 2 treatments (1.36 and $1.41 \%$ of diet DM, respectively). Dietary Ca was similar across all treatments, ranging from 0.75 to $0.83 \%$ of diet DM. No attempt was made to balance $\mathrm{Cl}$ among diets. Because of the higher $\mathrm{Cl}$ content in the alfalfa hay (0.83\%) compared with corn silage $(0.24 \%)$, dietary $\mathrm{Cl}$ was higher in the AHCS compared with the CS and CS-DCAD diets. The difference in $\mathrm{Cl}$ and $\mathrm{K}$ contents resulted in DCAD contents of 281, 251, and $336 \mathrm{mEq} /$ $\mathrm{kg}$ of diet DM for the AHCS, CS, and CS-DCAD diets, respectively. Ash content was much greater in the AHCS and CS-DCAD diets than in the CS diet but admittedly we did not succeed in matching the ash content between the AHCS and CS-DCAD diets, which was due in part to differences in $\mathrm{Cl}$ concentrations.

The CS-DCAD diet resulted in a remarkable increase in FE, 0.18 and 0.14 units, respectively, compared with the AHCS and CS diets. To put these differences in perspective, they could be compared with the improved FE due to dietary monensin addition. Symanowski et al. (1999), in an experiment involving 966 cows at 9 locations, reported that monensin increased $\mathrm{FE}$ from 1.50 to 1.56 when fed at rates between 0 to $321 \mathrm{mg} / \mathrm{cow}$ per day. The 0.06 unit change in FE due to monensin was only $40 \%$ of the response seen in our study with the addition dietary $\mathrm{K}$ and $\mathrm{Ca}$ to the CS diet.

Both the dietary RDP percentage (Table 1 ) and the MUN concentration (Table 2) were lowest in the CS diet, suggesting that inadequate RDP for maximal microbial fermentation might be a factor contributing to differences in FE. However, after accounting for dif- ferences in DMI, calculated total intakes of RDP were 2,435, 2,138, and 2,070 g/d in the AHCS, CS, and CS-DCAD treatments, respectively (Table 2). In fact, the lowest RDP intake was actually in the treatment with the highest FE. Also, the observed MUN in this study were 12.8, 12.4, and 13.7 for the AHCS, CS, and CS-DCAD treatments, respectively. These values are greater than the target MUN concentrations of 8 to 12 $\mathrm{mg} / \mathrm{dL}$ suggested by Kohn et al. (2002) after adjusting for BW and more importantly, analytical errors with early MUN analysis in the DHIA system. Finally, more recent work by Kalscheur et al. (2006), where RUP was held almost constant, showed no improvement in FE when diet RDP exceeded $9.6 \%$ of DM, the lowest diet concentration (CS diet) in the present study. Therefore, we do not believe that the observed FE response in the CS-DCAD diet was a function of inadequate RDP in the AHCS and CS diets.

In a meta-analysis of published work on DCAD effects in diets fed lactating dairy cows, $\mathrm{Hu}$ and Murphy (2004) estimated that dietary DCAD of 340,490 , and $400 \mathrm{mEq} / \mathrm{kg}$ of $\mathrm{DM}$ were required to maximize milk production, 4\% FCM, and DMI, respectively. The maximal DCAD in our study was in the CS-DCAD treatment $(336 \mathrm{mEq} / \mathrm{kg}$ of $\mathrm{DM})$, which was near the suggested maximal DCAD response for milk yield but well below the concentrations suggested by $\mathrm{Hu}$ and Murphy (2004) for maximum 4\% FCM milk yield and DMI (Hu and Murphy, 2004). Unfortunately, Hu and Murphy (2004) did not calculate FE in their metaanalysis, which precluded us from comparing our FE results with that study.

Although both $\mathrm{Na}$ and $\mathrm{K}$ were lower in the CS diet compared with the CS-DCAD diet, the largest differences were in $\mathrm{K}(1.18 \%$ vs. $1.41 \%)$, which also had the greatest effect on dietary DCAD, increasing it from 251 to $336 \mathrm{mEq} / \mathrm{kg}$ of diet DM. Mooney and Allen (2007) compared FE responses using $\mathrm{NaHCO}_{3}$ and $\mathrm{K}_{2} \mathrm{CO}_{3}$ to increase DCAD from 251 to 367 and 348 $\mathrm{mEq} / \mathrm{kg}$, respectively. They showed $0.06-$ and 0.08 -unit increases in FE with $\mathrm{NaHCO}_{3}$ and $\mathrm{K}_{2} \mathrm{CO}_{3}$ but no effect of increasing dietary $\mathrm{Na}$ or $\mathrm{K}$ by the same amount with added $\mathrm{NaCl}$ or $\mathrm{KCl}$, supplements that would not change DCAD. Similarly, calculated FE from treatment means published by Wildman et al. (2007) show a 0.10unit increase in FE by increasing dietary $\mathrm{Na}$ from 0.25 to $0.51 \%$ and $\mathrm{K}$ from $1.05 \%$ to $1.56 \%$ of diet DM by adding $0.97 \% \mathrm{NaHCO}_{3}$ and $0.97 \% \mathrm{~K}_{2} \mathrm{CO}_{3}$, respectively, to the diet. Thus, the improvement of FE in the present experiment with increased dietary $\mathrm{K}$ and DCAD is consistent with results of other recent experiments.

An underlying question with improved $\mathrm{FE}$ with added dietary $\mathrm{K}$ or the indirect effect of dietary $\mathrm{K}$ on DCAD is why such a response would occur. The 
minimum required dietary concentrations for lactating sows, laying hens, lactating beef cattle, and lactating dairy cattle are $0.18,0.10,0.15$, and $0.15 \%$, respectively, for Na; $0.12,0.11,0.08$, and $0.25 \%$, respectively, for $\mathrm{Cl}$; and $0.20,0.25,0.80$, and $1.25 \%$, respectively, for $\mathrm{K}$ (NRC, 1998, 1994, 1996, 2001, respectively). Although $\mathrm{Na}$ and $\mathrm{Cl}$ requirements are similar between species, $\mathrm{K}$ requirements are much higher in beef and dairy cattle than in poultry and swine. Theoretically, the underlying mineral metabolism and physiology among these species would be expected to be similar. However, major differences exist between species in their digestive physiology, with swine and poultry being monogastrics and beef and dairy cattle being ruminant animals. Ruminants employ bacterial fermentation as a key part of their digestion processes. Perhaps, the much greater K requirement and, in turn, the greater DCAD is required for maximal bacterial fermentation rather than as a direct physiological need of the cow? Dietary buffers (Erdman, 1988) have been shown to increase rumen $\mathrm{pH}$ and alter rumen VFA patterns, and addition of dietary $\mathrm{NaHCO}_{3}$ was shown to increase digestibility in early lactation dairy cows (Erdman et al., 1982). Although we did not measure changes in rumen fermentation or digestibility in this study, enhanced rumen fermentation and increased diet digestibility would explain the large increases in FE found in this and other experiments.

\section{ACKNOWLEDGMENTS}

The authors gratefully acknowledge Benny Erez, Brian Spielman, and Michael Dwyer at the Central Maryland Research and Education Dairy Unit, Clarksville, for their assistance with animal care and data collection during these studies. The authors also acknowledge partial financial support provided by Church and Dwight Inc. (Piscataway, NJ).

\section{REFERENCES}

Dhiman, T. R., and L. D. Satter. 1997. Yield response of dairy cows fed different proportions of alfalfa silage and corn silage. J. Dairy Sci. 80:2069-2082.

Erdman, R. A. 1988. Dietary buffering requirement of lactating dairy cows: A review. J. Dairy Sci. 71:3246-3266.

Erdman, R. A., R. W. Hemken, and L. S. Bull. 1982. Dietary sodium bicarbonate and magnesium oxide for early postpartum lactating dairy cows. Effects on production, acid-base metabolism, and digestion. J. Dairy Sci. 65:712-731.
Grieve, D. G., J. B. Stone, G. K. MacLeod, and R. A. Curtis. 1980. All silage forage programs for dairy cattle. II. Performance through three lactations. J. Dairy Sci. 63:594-600.

Hemken, R. W., and J. H. Vandersall. 1967. Feasibility of an all-silage forage program. J. Dairy Sci. 50:417-422.

Hu, W., and M. R. Murphy. 2004. Dietary cation-anion difference effects on performance and acid-base status of lactating dairy cows: A meta-analysis. J. Dairy Sci. 87:2222-2229.

Jasaitis, D. K., J. E. Wohlt, and J. L. Evans. 1987. Influence of feed ion content on buffering capacity of ruminant feedstuffs in vitro. J. Dairy Sci. 70:1391-1403.

Jordan, E. R., and R. H. Fourdraine. 1993. Characterization of the management practices of the top milk producing herds in the country. J. Dairy Sci. 76:3247-3256.

Kalscheur, K. F., R. L. Baldwin VI, B. P. Glenn, and R. A. Kohn. 2006. Milk production of dairy cows fed differing concentrations of rumen-degraded protein. J. Dairy Sci. 89:249-259.

Kellogg, D. W., J. A. Pennington, Z. B. Johnson, and R. Panivivat. 2001. Survey of management practices used for the highest producing DHI herds in the United States. J. Dairy Sci. 84(E. Suppl.):E120-E127.

Kohn, R. A. 2000. Three conditions of the ruminal milieu that determine pH. in Rumen Function Conference, 2000, Chicago, IL.

Kohn, R. A., K. F. Kalscheur, and E. Russek-Cohen. 2002. Evaluation of models to estimate urinary nitrogen and expected milk urea nitrogen. J. Dairy Sci. 85:227-233.

Mooney, C. S., and M. S. Allen. 2007. Effect of dietary strong ions on chewing activity and milk production in lactating dairy cows. J. Dairy Sci. 90:5610-5618.

NRC. 1994. Nutrient Requirements of Poultry. 9th rev. ed. Natl. Acad. Sci., Washington, DC.

NRC. 1996. Nutrient Requirements of Beef Cattle. 7th rev. ed. Natl. Acad. Sci., Washington, DC.

NRC. 1998. Nutrient Requirements of Swine. 10th rev. ed. Natl. Acad. Sci., Washington, DC.

NRC. 2001. Nutrient Requirements of Dairy Cattle. 7th rev. ed. Natl. Acad. Sci., Washington, DC.

Stewart, P. A. 1983. Modern quantitative acid base chemistry. Can. J. Physiol. Pharmacol. 61:1444-1461.

Symanowski, J. T., H. B. Green, J. R. Wagner, J. I. D. Wilkinson, J. S. Davis, M. R. Himstedt, M. S. Allen, E. Block, J. J. Brennan, H. H. Head, J. J. Kennelly, J. N. Nielsen, J. E. Nocek, J. J. van Der List, and L. W. Whitlow. 1999. Milk production and efficiency of cows fed monensin. J. Dairy Sci. 82(Suppl.1):75. (Abstr.)

Thomas, J. W., J. D. Brown, and R. S. Emery. 1970. Corn silage compared to alfalfa hay for milking cows when fed various levels of grain. J. Dairy Sci. 53:342-350.

Trimberger, G. W., H. F. Tyrrell, D. A. Morrow, J. T. Reid, M. J. Wright, W. F. Shipe, W. G. Merrill, J. K. Loosli, C. E. Coppock, L. A. Moore, and C. H. Gordon. 1972. Effects of liberal concentrate feeding on health, reproductive efficiency, economy of milk production, and other related responses of the dairy cow. New York's Food and Life Sci. Bull. No 8., Cornell University, Ithaca, NY.

USDA-NASS. 2010. Crop Production Historical Track Records. Accessed Dec. 22, 2010. http://usda.mannlib.cornell.edu/usda/current/htrcp/htrcp-04-12-2010.pdf.

Wildman, C. D., J. W. West, and J. K. Bernard. 2007. Effect of dietary cation-anion difference and dietary crude protein on milk yield, acid-base chemistry, and rumen fermentation. J. Dairy Sci. 90:4693-4700. 